\title{
ホイスラー化合物熱電材料の新展開
}

\author{
西野洋一 \\ 名古屋工業大学大学院工学研究科未来材料創成工学専攻
}

J. Japan Inst. Met. Mater. Vol. 79, No. 11 (2015), pp. 548-554

Special Issue on Progresses in the Development of Thermoelectric Materials: New Analyses and New Materials (C) 2015 The Japan Institute of Metals and Materials OVERVIEW

\section{New Development of Thermoelectric Materials Based on Heusler Compounds}

\author{
Yoichi Nishino
}

Department of Frontier Materials, Graduate School of Engineering, Nagoya Institute of Technology, Nagoya 466-8555

The Heusler-type $\mathrm{Fe}_{2} \mathrm{VAl}$-based compounds can be a possible candidate for new thermoelectric materials. A significant enhancement in the Seebeck coefficient with both positive and negative sign can be achieved not only by the Fe/V off-stoichiometry combined with doping but also by the $\mathrm{V} / \mathrm{Al}$ off-stoichiometry even without doping. For the latter alloys, the peak temperature of the Seebeck coefficient increases up to $600 \mathrm{~K}$, and the maximum power factor is $4.3 \times 10^{-3}$ for $\mathrm{p}$-type and $6.8 \times 10^{-3} \mathrm{~W} / \mathrm{mK}^{2}$ for $\mathrm{n}$-type, both of which are higher than those of the half-Heusler compound $\mathrm{ZrNiSn}$ and $\mathrm{Mg}_{2} \mathrm{Si}$ compound. A large power factor is required for practical applications of automotive thermoelectric generators. The heavy element Ta doping for the V/Al offstoichiometric alloys is effective in increasing the dimensionless figure of merit at around $500 \mathrm{~K}$.

[doi:10.2320/jinstmet.JA201503]

(Received April 16, 2015; Accepted May 19, 2015; Published November 1, 2015)

Keywords: Heusler compound, $\mathrm{Fe}_{2} \mathrm{VAl}$, pseudogap, off-stoichiometry, valence electron concentration, thermoelectric materials

\section{1. は じめに}

ホイスラー化合物は, $\mathrm{X}_{2} \mathrm{YZ}(\mathrm{X}, \mathrm{Y}:$ 遷移金属元素, $\mathrm{Z}: \mathrm{sp}$ 元素)の化学組成で L $2{ }_{1}$ 構造 (ホイスラー構造)をもつ金属間 化合物であり, 強磁性形状記憶合金, 熱電变換材料, 八ーフ メタル材料など, さまざまな機能材料として高いポテンシャ ルを有する ${ }^{1)}$ 。これは, ホイスラー構造に特有の電子構造が 材料の機能に直結しているためであるといえる.なかでも $\mathrm{Fe}_{2} \mathrm{VAl}$ は，強磁性の遷移金属を含むにもかかわらず，強磁 性がまさに消失する境界にある，この合金の電気抵抗率は 2 $\mathrm{K}$ で $30 \mu \Omega \mathrm{m}$ にも達しており, 半導体的な負の温度依存性 を示すことが特徵である ${ }^{2)}$. また，バンド計算によれば $\mathrm{Fe}_{2} \mathrm{VAl}$ は典型的な擬ギャップ系である ${ }^{3,4)}$. 擬ギャップ系々 は，バンドギャップが開いていないので厳密には金属である が，フェルミ準位に拈ける状態密度がきわめて小さい物質群 のことであり, $\mathrm{Bi}$ やグラファイトのような半金属に特徵的 なバンド構造である.

このように特異な電子構造をもつ $\mathrm{Fe}_{2} \mathrm{VAl}$ ホイスラー化合 物について, 次節で説明する擬ギャップ工学に基づいて熱電 材料設計を行うことにより，ゼーベック係数 $S$ が増大する と同時に電気抵抗率 $\rho$ が減少する。このとき, 熱電材料か ら取り出せる最大電力の指標として出力因子 $P\left(=S^{2} / \rho\right)$ を評 価すると, 従来の $\mathrm{Bi}_{2} \mathrm{Te}_{3}$ 系を上回る発電性能を実現してい る5,6). さらに, 熱電材料としては出力因子 $P$ が大きいだけ
でなく, 温度差を与えたとき熱電变換に利用されない熱流を 少なくするために熱伝導率 $\kappa$ を小さくしなければならず, 高い性能指数 $Z(=P / \kappa)$ が必要である. 実際, 熱電材料とし て実用化するための目安として無次元性能指数 $Z T=1$ 以上 $\left(T\right.$ : 絶対温度)の性能が要求されるが, $\mathrm{Fe}_{2} \mathrm{VAl}$ 系熱電材料 については, $\mathrm{Bi}_{2} \mathrm{Te}_{3}$ 系と比べて熱伝導率 $\kappa$ が一桁も大きい ので $Z T=1$ を満たすことは困難である，ところが，自動車 や自動二輪車のような移動体における熱電発電に応用する場 合には，必ずしも $Z T$ の大きさのみで有用性が決まるわけで はなく, 熱源(排気系統)に影響しない適度な熱伝導特性を有 する材料の方がむしろ都合がよいといえる．しかも，有害元 素を含まず資源性に優れて抢り，走行中の振動や熱サイクル に対する耐久性を兼ね備えた材料が求められる7)。このよう な条件を満足するのが $\mathrm{Fe}_{2} \mathrm{VAl}$ 系熱電材料である.

一方, 熱電材料は特定の温度域で高い性能を示すため, 熱 源温度に対応した材料を選択する必要がある.たとえば, 移 動体の内燃機関から排出される熱エネルギーを利用すること を想定した場合には，エンジン燃焼部近傍の限られた領域で は $1000 \mathrm{~K}$ 以上の高温になるが，マフラー部など大部分の排 気系統では走行中のエンジン回転数のときでも $500 \sim 600 \mathrm{~K}$ 程度である. そのため, 排気系統の熱エネルギーを有効利用 するには, 室温から $500 \mathrm{~K}$ 程度の温度域で高い発電性能を 示す熱電材料を選択しなければならない7). 最近の研究8,9)に よれば, $\mathrm{Fe}_{2} \mathrm{VAl}$ 系熱電材料において, 化学量論組成からわ ずかにずらすだけでゼーベック係数が増大すると同時にピー 
ク温度も高温側ヘシフトすることが見出されている。つま り，熱源温度に応じて自在に熱電性能のピーク温度を調整す ることが可能である.

本稿では，まずホイスラー化合物熱電材料について，擬ギ ヤップ工学に基づく材料設計の方法と熱電性能の現状を明ら かにする．さらに， $\mathrm{Fe}_{2} \mathrm{VAl}$ 系熱電材料について非化学量論 組成の効果を巧久に利用して高温での性能を大幅に向上する 方法について紹介する．移動体のように膨大な廃熱が持続的 に発生する状況では, 性能指数よりもむしろ出力因子のよう な発電性能が高い材料を用いる方が有利であると考えられる ので，ZTによらない材料開発の重要性および実用化の可能 性について述べる。

\section{2. 擬ギャップ工学による熱電材料設計}

一般に，擬ギャップ系ではフェルミ準位 $E_{\mathrm{F}}$ における状態 密度が小さく，また $E_{\mathrm{F}}$ 近傍の状態密度の立ち上がりも急峻 になっている．このように鋭い状態密度のピークをもつ物質 は，優れた熱電特性を示す可能性があることが指摘されてい る10). Mottの理論によれば，ゼーベック係数 $S$ は式 $(1$ )の ように表わすことができる11)

$$
S=-\frac{\pi^{2}}{3} \frac{k_{\mathrm{B}}^{2} T}{e}\left\{\frac{d \ln N(E)}{d E}\right\}_{E=E_{\mathrm{F}}}
$$

ここで， $k_{\mathrm{B}}$ はボルッマン定数である.式 $(1)$ によば, ゼーベック係数はフェルミ準位 $E_{\mathrm{F}}$ に打ける状態密度 $N\left(E_{\mathrm{F}}\right)$ に反比例し，そのエネルギー勾配 $d N(E) / d E$ に比例する. このため，擬ギャップ内でフェルミ準位のエネルギー位置を 最適化することによりゼーベック係数は増大する可能性があ る.さらに, 電気伝導率 $\sigma$ は式 $(2$ )のように表わすことが できる。

$$
\sigma=\frac{1}{\rho}=\frac{e^{2}}{3} \Lambda_{\mathrm{F}} v_{\mathrm{F}} N\left(E_{\mathrm{F}}\right)
$$

ここで， $\Lambda_{\mathrm{F}}$ と $v_{\mathrm{F}}$ はそれぞれフェルミ面上の電子の平均自由 行程とフェルミ速度である. 電気抵抗率 $\rho$ は $N\left(E_{\mathrm{F}}\right)$ に反比 例するので，フェルミ準位が擬ギャップの中心からシフトす ると，ゼーベック係数が増大するとともに電気抵抗率も減少 することになる．

$\mathrm{Fe}_{2} \mathrm{VAl}$ においてフェルミ準位を制御するには，化学量論 組成からずらす方法12-14)のほか，元素部分置換の方法15-21) が有効であり，後者の場合はホイスラー構造における置換元 素のサイト選択性を利用することができる5,6). そのため， 規則構造をあまり乱すことなく，元素置換が可能である。 と くに, $\mathrm{Fe}_{2} \mathrm{VAl}$ の $\mathrm{V}$ サイについては周期表で $\mathrm{V} よ り$ 左側 の遷移元素で置換することができ，たとえば Ti や Zr で部 分置換すると, 総価電子数が減少するのでゼーベック係数は 正の值を示す。一方，Vより右側にある元素，たとえば Mo や W で部分置換するとゼーベック係数は負の值になる．さ らに，Al サイトについては IVB 属の $\mathrm{Si}$ や $\mathrm{Ge}$ で置換するこ とができるので，やはり電子の割合が増加してゼーベック係 数は負の大きな值を示すようになる. このように置換元素に よってゼーベック係数の正負の符号も变化するため, 熱電材 料として p-n 特性を制御することができる.

\section{3. 非化学量論組成を利用した材料設計}

\section{$3.1 \mathrm{Fe} / \mathrm{V}$ 非化学量論組成の効果}

$\mathrm{Fe}_{2} \mathrm{VAl}$ に打いて元素置換した場合，フェルミ準位 $E_{\mathrm{F}}$ が 剛体バンド的に変化するだけであるため, 熱電特性を飛躍的 に向上させることは困難である。ところが， $\mathrm{Fe}_{2} \mathrm{VAl}$ の $\mathrm{Fe} / \mathrm{V}$ 比を化学量論組成からわずかにずらすことにより，擬 ギャップ構造を大きく崩すことなく $E_{\mathrm{F}}$ 近傍のバンド構造を 変化させることができる．実際，化学量論組成からわずかに ずらしても粉末 X 線回折による規則度にはほとんど影響は ないが，スーパーセルを用いたバンド計算 ${ }^{22}$ では，組成ず れによってアンチサイトを占有した遷移金属の d 状態が擬 ギャップ内に出現することが予測されている，このような擬 ギャップ内の状態密度変化のため, 非化学量論組成の合金に 元素置換を行った場合には，化学量論組成をべースとする合 金のゼーベック係数よりも増大する可能性がある.

$\mathrm{Fe} / \mathrm{V}$ 非化学量論組成の効果を明らかにするために,

Fig. 1 に $\mathrm{Fe}_{2-x} \mathrm{~V}_{1+x} \mathrm{Al}_{1-y} \mathrm{Si}_{y}, \quad \mathrm{Fe}_{2-x} \mathrm{~V}_{1+x-y} \mathrm{Ti}_{y} \mathrm{Al}$ および $\mathrm{Fe}_{2-x-y} \mathrm{Ir}_{y} \mathrm{~V}_{1+x} \mathrm{Al}$ 合金のゼーベック係数 $S$ を価電子濃度 $V E C$ に対して整理した結果を示す ${ }^{23)}$. ここでの組成 $x$ と $y$ はいずれも仕达久組成であるが，化学分析による組成とのず れは $0.2 \%$ 以下である。化学量論組成の $\mathrm{Fe}_{2} \mathrm{VAl}(x=0)$ の $V E C$ は 6 であるが，元素置換により $V E C<6$ になるとゼ一 ベック係数の符号は正で, $V E C>6$ では負の大きな值を示し ている．その結果， $V E C=6$ を中心としてゼーベック係数の 符号は正から負に急激に変化しており，置換元素の種類によ らずにすべてのデータがユニバーサルな 1 本の曲線にのっ ていることがわかる．このことから，一連の $\mathrm{Fe}_{2} \mathrm{VAl}$ 系化合 物は典型的な電子化合物であるといえる，なお，電子化合物 の電子濃度パラメータとしては $e / a$ がしばしば用いられるが,

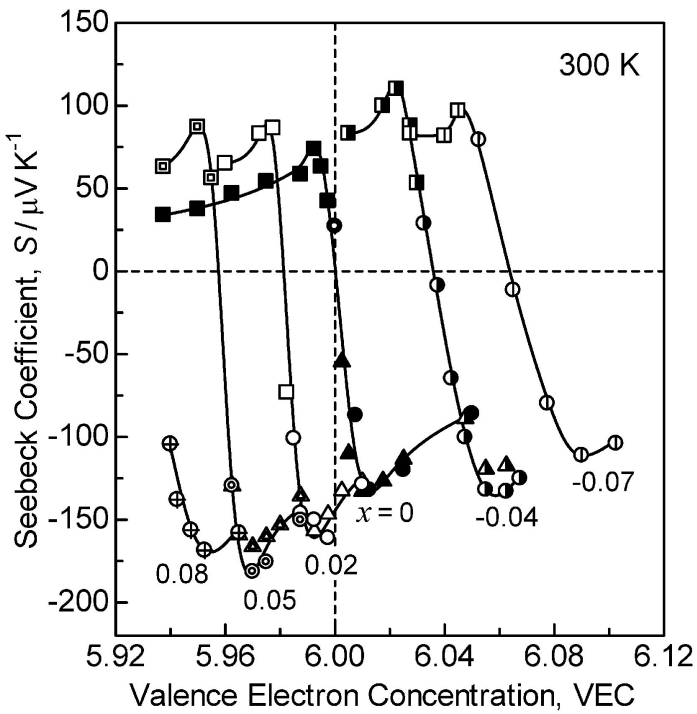

Fig. 1 Seebeck coefficient at $300 \mathrm{~K}$ against valence electron concentration ( VEC) in $\mathrm{Fe}_{2-x} \mathrm{~V}_{1+x} \mathrm{Al}_{1-y} \mathrm{Si}_{y}$ (circles), $\mathrm{Fe}_{2-x} \mathrm{~V}_{1+x-y} \mathrm{Ti}_{y} \mathrm{Al}$ (squares) and $\mathrm{Fe}_{2-x-y} \operatorname{Ir}_{y} \mathrm{~V}_{1+x} \mathrm{Al}$ (triangles). The $V E C$ for $\mathrm{Fe}_{2} \mathrm{VAl}$ is equal to 6 . The data on the stoichiometric $(x=0)$ and off-stoichiometric alloys are plotted by the closed and open symbols, respectively. 
$e / a$ と VECの相違については Mizutani ${ }^{24)} に よ り$ 詳細に論じ られている.

化学量論組成より Vリッチの合金 $(x=0.02,0.05,0.08)$ に 対して元素置換すると, 化学量論組成の合金 $(x=0)$ と同様に 組成 $x$ に応じてすべてのデータが 1 本の曲線にのるが， $x=0$ の場合よりも $V E C$ のさい方に曲線が全体的にシフトして いる. さらに， $x=0$ と比較するとゼーベック係数の絶対值 が大きくなっており，とくに $\mathrm{n}$ 型熱電特性の増大が顕著で, $x=0.05$ の合金では最高で $S=-180 \mu \mathrm{V} / \mathrm{K}$ にも達してい る.したがって, 非化学量論組成の効果により $E_{\mathrm{F}}$ 近傍のバ ンド構造が変化し, さらに元素置換により $E_{\mathrm{F}}$ が最適なエネ ルギー位置にシフトしていると考えられる. 反対に, Fe リ ッチ合金 $(x=-0.04,-0.07)$ では $x=0$ よりも VEC が大きい 方に曲線はシフトしている.この場合は $\mathrm{p}$ 型熱電特性の増 大が顕著で， $x=-0.04$ では $S=110 \mu \mathrm{V} / \mathrm{K}$ を示しており， 化学量論組成の合金やVリッチ合金を上回っている.

以上のように，化学量論組成の $\mathrm{Fe}_{2} \mathrm{VAl}$ に元素置換した場 合と比べて, 非化学量論組成をべースとする合金ではゼーべ ック係数の絶対值は大幅に増大する. とくに $\mathrm{n}$ 型性能の向 上には Vリッチ合金に元素置換する方法が効果的であり, p 型については Feリッチ合金をべースとする材料設計が有効 である. 最近になって, 非化学量論組成の合金におけるゼー ベック係数増大の起源を明らかにするために，放射光を用い た $\mathrm{X}$ 線光電子分光法による電子構造の研究も行われてい $ろ^{25)}$.

擬ギャップ工学に基づいて $\mathrm{Fe}_{2} \mathrm{VAl}$ 系化合物の熱電材料設 計をすることにより, 電気抵抗率 $\rho$ が急激に減少するにも かかわらず，ゼーベック係数 $S$ は敏感に増大する.これは 擬ギャップ系の大きな特徵であり, 熱電材料の観点から最も 好都合な特性である.ここで重要となる性能は出力因子 $P\left(=S^{2} / \rho\right)$ である. 化学量論組成の $\mathrm{Fe}_{2} \mathrm{VAl}$ では出力因子は $10^{-4} \mathrm{~W} / \mathrm{mK}^{2}$ のオーダーで非常に小さい16). ところが， $\mathrm{Si}$ 置換合金のゼーベック係数は室温付近でー $130 \mu \mathrm{V} / \mathrm{K}$ を示し ており， $\mathrm{n}$ 型熱電材料として $P=5.4 \times 10^{-3} \mathrm{~W} / \mathrm{mK}^{2}$ という 大きな出力因子が得られている15). $\mathrm{Bi}_{2} \mathrm{Te}_{3}$ 系熱電材料でも $P=4 \sim 5 \times 10^{-3} \mathrm{~W} / \mathrm{mK}^{2}$ であるので26)，これを上回る大きさ となっている.さらに, 非化学量論組成の Vリッチ合金を ベースとして Si 置換すると室温付近で $P=6.7 \times 10^{-3} \mathrm{~W} /$ $\mathrm{mK}^{2}$ にも達しており ${ }^{23)}, \mathrm{Fe} / \mathrm{V}$ 非化学量論組成の効果がきわ めて有効であることがわかる，一方， Ti 置換合金は $\mathrm{p}$ 型で あるが，本来 $\mathrm{n}$ 型に比べるとゼーベック係数が小さいた め, 出力因子は $2.5 \times 10^{-3} \mathrm{~W} / \mathrm{mK}^{2}$ 程度である16). しかし, 非化学量論組成の Fe リッチ合金をべースとして Ti 置換す ると $P=3.9 \times 10^{-3} \mathrm{~W} / \mathrm{mK}^{2}$ となり ${ }^{23)}, \mathrm{Bi}_{2} \mathrm{Te}_{3}$ 系にも匹敵す る出力因子が得られている.

\section{$3.2 \mathrm{~V} / \mathrm{Al}$ 非化学量論組成の効果}

$\mathrm{Fe}_{2} \mathrm{VAl}$ において $\mathrm{Fe} / \mathrm{V}$ 比を非化学量論組成にすること で，前節で述べたようにフェルミ準位近傍のバンド構造が変 化する可能性がある。これに対して，V/Al 比を非化学量論 組成にした場合は結晶構造やバンド構造への影響はあまり大 きくないが，その代わりキャリア数が大きく変化する．この
ため，元素置換をしなくても熱電特性の大幅な変化が期待で きる. Fig. 2 は, $\mathrm{Fe}_{2} \mathrm{~V}_{1+{ }_{x}} \mathrm{Al}_{1-x}(-0.12 \leq x \leq 0)$ におけるゼ一 ベック係数の温度依存性である ${ }^{8)} \cdot \operatorname{Fe}_{2} \operatorname{VAl}(x=0)$ のゼーベッ ク係数は正の值をとり，20〜 $30 \mu \mathrm{V} / \mathrm{K}$ の範囲で緩やかな温 度依存性を示している．ここで，Alリッチ合金は $V E C<6$ であるので $\mathrm{p}$ 型でゼーベック係数が増大しており， $x=$ - 0.03 に拈いて最大で $100 \mu \mathrm{V} / \mathrm{K}$ を超えている.これは, 図中に示したように化学量論組成の $\mathrm{Fe}_{2} \mathrm{VAl}$ に Ti 置換した 合金 ${ }^{16)}$ よりも大きく, $\mathrm{Fe} / \mathrm{V}$ 非化学量論組成の $\mathrm{Ti}$ 置換合 金 ${ }^{23)}$ と同等の值である.さらに，Fig. 2 で注目すべき点は, 組成 $|x|$ の増加にともなってゼーベック係数のピーク温度が 高温側にシフトしていくことであり， $x=-0.12$ において $600 \mathrm{~K}$ にまで達している．また，組成 $|x|$ が大きくなると ゼーベック係数のピーク值は減少するものの, ピーク形状は 緩やかになるため, 広範囲の温度域で比較的高いゼーベック

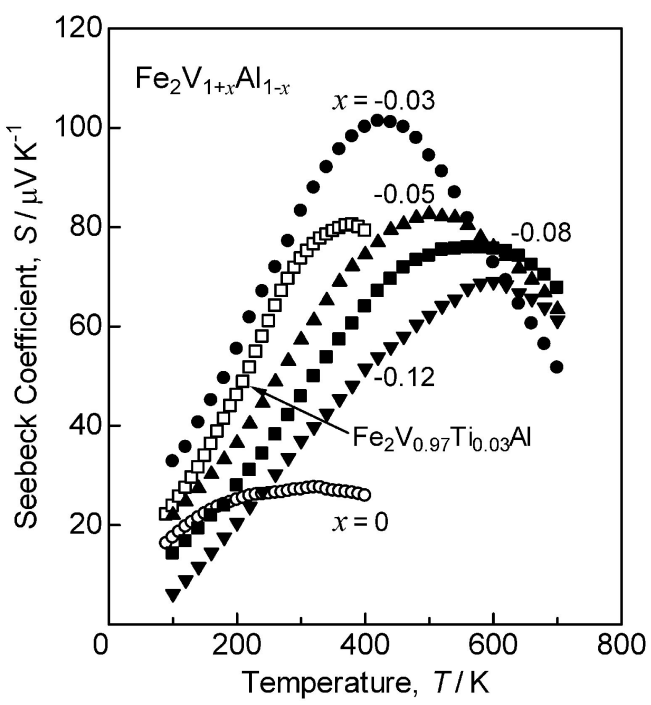

Fig. 2 Temperature dependence of Seebeck coefficient $S$ in $\mathrm{Fe}_{2} \mathrm{~V}_{1+x} \mathrm{Al}_{1-x}$ with $-0.12 \leq x \leq 0$. For comparison, the data on $\mathrm{Fe}_{2} \mathrm{~V}_{0.97} \mathrm{Ti}_{0.03} \mathrm{Al}{ }^{16)}$ is also shown.

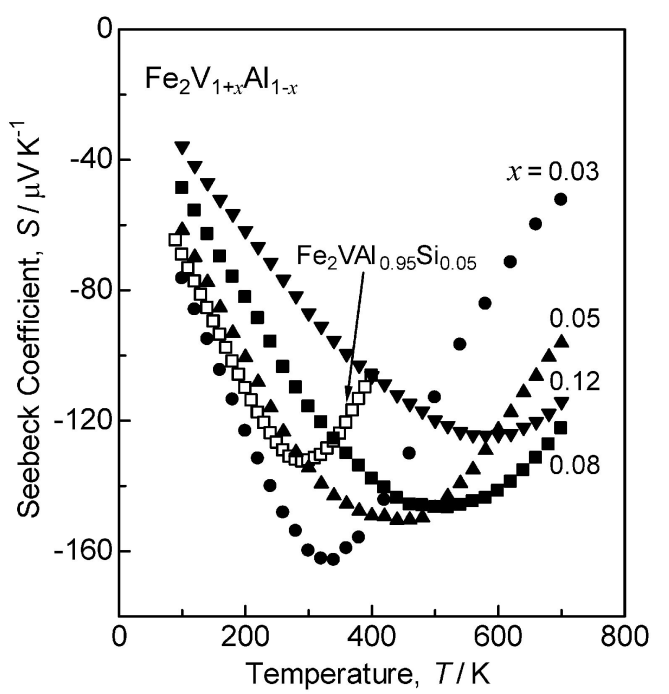

Fig. 3 Temperature dependence of Seebeck coefficient $S$ in $\mathrm{Fe}_{2} \mathrm{~V}_{1+x} \mathrm{Al}_{1-x}$ with $0.03 \leq x \leq 0.12$. For comparison, the data on $\mathrm{Fe}_{2} \mathrm{VAl}_{0.95} \mathrm{Si}_{0.05}{ }^{15)}$ is also shown. 
係数が保たれている.

Fig. 3 は， $\mathrm{Fe}_{2} \mathrm{~V}_{1+x} \mathrm{Al}_{1-x}(0.03 \leq x \leq 0.12)$ に打けるゼーべ ック係数の温度依存性である ${ }^{8)}$. V リッチ合金は $V E C>6$ で あるので, $\mathrm{n}$ 型でゼーベック係数の絶対值は大幅に増大して いる. とくに， $x=0.03$ において最高でー $163 \mu \mathrm{V} / \mathrm{K}$ にまで 達しており，これは $\mathrm{Fe} / \mathrm{V}$ 非化学量論組成の $\mathrm{Si}$ 置換合金 ${ }^{23)}$ よりは小さいものの, 図中に示した化学量論組成の $\mathrm{Si}$ 置換 合金15)よりも明らかに大きいことがわかる．また，組成 $x$ の 増加にともなってゼーベック係数のピーク温度が高温側にシ フトしており， $x=0.12$ において $580 \mathrm{~K}$ にまで達するが， ピーク形状は徐々に緩やかになる傾向がある。このような ピーク温度の上昇は, 擬ギャップのエネルギー幅の増加に起 因している可能性もあるので, 今後, 電子構造変化について 詳細に調べていく必要がある27).

以上のように，V/Al 非化学量論組成の合金では，元素置 換しなくても元素置換した合金と同様にゼーベック係数が増 大するとともに電気抵抗率が減少することが特徵である.

Fig. 4 に, $\mathrm{n}$ 型の $\mathrm{Fe}_{2} \mathrm{~V}_{1+x} \mathrm{Al}_{1-x}(0.03 \leq x \leq 0.12)$ に打ける出 力因子 $P$ の温度依存性を示す ${ }^{8)}$. 組成 $x$ とともに出力因子は 増大し， $x=0.05$ で $P=6.8 \times 10^{-3} \mathrm{~W} / \mathrm{mK}^{2}$ となり， $\mathrm{Fe} / \mathrm{V}$ 非 化学量論組成に元素置換した合金 ${ }^{23)}$ に敵する大きさを示 す.さらに，組成 $x$ が大きくなると出力因子のピーク温度は 高温側にシフトしていくが，この変化はゼーベック係数の ピーク温度の上昇に対応している，また，環境調和型熱電材

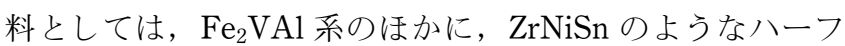
ホイスラー化合物や $\mathrm{Mg}_{2} \mathrm{Si}$ 化合物がよく知られている.

Fig. 4 には，比較のために $\mathrm{Zr}_{0.98} \mathrm{Nb}_{0.02} \mathrm{NiSn}{ }^{28)}$ と $\mathrm{Sb}$ をドー プした $\mathrm{Mg}_{2} \mathrm{Si}^{29)}$ の出力因子も示してある.これらはすべて $\mathrm{n}$ 型材料のデータであるが，少なくとも $700 \mathrm{~K}$ 以下の温度範 囲では， $\mathrm{Fe}_{2} \mathrm{VAl}$ 系の出力因子の方がかなり大きいことがわ かる.

一方, Fig. 5 に p 型の $\mathrm{Fe}_{2} \mathrm{~V}_{1+x} \mathrm{Al}_{1-x}(-0.12 \leq x \leq-0.03)$ に抢ける出力因子 $P$ の温度依存性を示す ${ }^{8)} . \mathrm{p}$ 型材料は $\mathrm{n}$ 型

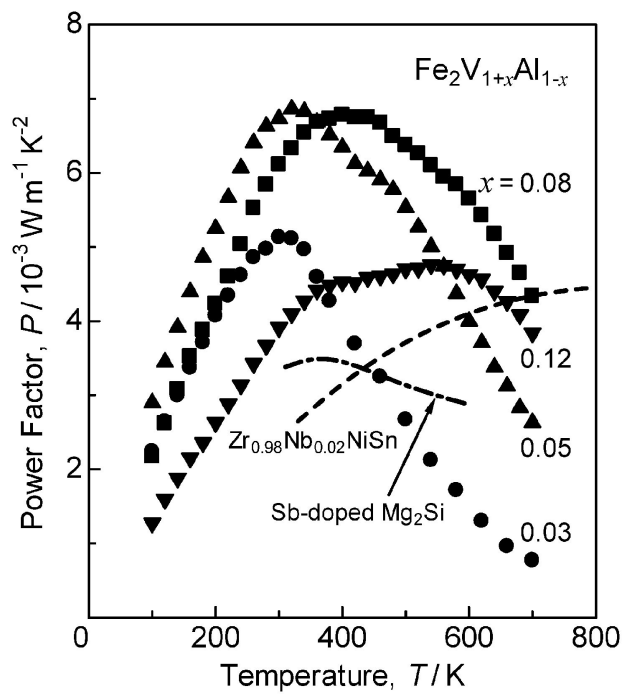

Fig. 4 Temperature dependence of power factor $P$ in $\mathrm{Fe}_{2} \mathrm{~V}_{1+x} \mathrm{Al}_{1-x}$ with $0.03 \leq x \leq 0.12$. Also plotted in the figure are the values of $P$ for $\mathrm{Zr}_{0.98} \mathrm{Nb}_{0.02} \mathrm{NiSn}{ }^{28)}$ and $\mathrm{Sb}$-doped $\mathrm{Mg}_{2} \mathrm{Si}^{29)}$
に比べてゼーベック係数が小さいため, 出力因子も Fig. 4 と比較して全体に小さくなっている。 それでも $x=-0.03$ の 合金の最大值は $P=4.3 \times 10^{-3} \mathrm{~W} / \mathrm{mK}^{2}$ を示しており, $\mathrm{Fe} / \mathrm{V}$ 非化学量論組成の合金に Ti 置換した場合 ${ }^{23)}$ より大きくなっ ている.さらに， p 型のハーフホイスラー化合物 $\mathrm{Zr}_{0.5} \mathrm{Hf}_{0.5} \mathrm{CoSb}_{0.8} \mathrm{Sn}_{0.2}{ }^{30)}$ と $\mathrm{Ag}$ ドープした $\mathrm{Mg}_{2} \mathrm{Si}^{31)}$ について も比較して示してある. ハーフホイスラー化合物は約 $700 \mathrm{~K}$ 付近にピークがあるので高温性能に優れているが，550 K 以 下の温度範囲では $\mathrm{p}$ 型としても $\mathrm{Fe}_{2} \mathrm{VAl}$ 系の方が出力因子の 高い熱電材料である.

\section{$3.3 \mathrm{~V} / \mathrm{Al}$ 非化学量論組成と重元素置換の複合効果}

$\mathrm{V} / \mathrm{Al}$ 非化学量論組成にすることにより， $\mathrm{p}$ 型と $\mathrm{n}$ 型とも にゼーベック係数の絶対值が増大すると同時にピーク温度が 高温側にシフトする。このような特性は，より高温の廃熱を 利用する熱電発電にとって大変都合がよいが，さらに性能指 数を向上するためには熱伝導率を低減する必要がある。これ まで $\mathrm{Fe}_{2} \mathrm{VAl}$ 系熱電材料では，重元素置換や粉末治金法を用 いて焼結体とすることで熱伝導率の低減が行われている。 そ こで，V/Al 非化学量論組成にする代わりに，V と同属の重 元素である $\mathrm{Ta}$ で部分置換した合金 $\mathrm{Fe}_{2} \mathrm{VTa}_{x} \mathrm{Al}_{1-x}$ の熱電特 性を紹介する。

$\mathrm{Fe}_{2} \mathrm{VTa}_{x} \mathrm{Al}_{1-x}$ に打いて, $\mathrm{Fe}, \mathrm{V}, \mathrm{Al}$ 原子の各サイト占有 率についてリートベルト法により調べた結果を Fig. 6(a)に 示す ${ }^{9)}$. Fe 原子の $\mathrm{Fe}$ サイト占有率は $\mathrm{Ta}$ 組成によらず誤差 範囲内で 1 であるが， $\mathrm{Al}$ 原子の $\mathrm{Al}$ サイト占有率は $\mathrm{Ta}$ 置換 とともに減少している。一方， $\mathrm{V}$ 原子の $\mathrm{V}$ サイト占有率も $\mathrm{A} 1$ 原子と同様に $\mathrm{Ta}$ 置換とともに減少していく，つまり， V 原子は $\mathrm{Al}$ サイトを占有し, 空席となった $\mathrm{V}$ サイトを $\mathrm{Ta}$ 原 子が占有する可能性がある. Fig. 6(b) には，V 原子の $\mathrm{Al}$ 少 イト占有率， $\mathrm{Ta}$ 原子の $\mathrm{V}$ サイト抢よび $\mathrm{Al}$ サイト占有率の $\mathrm{Ta}$ 組成依存性を示す， V 原子の $\mathrm{Al}$ サイト占有率および $\mathrm{Ta}$ 原子の $\mathrm{V}$ サイト占有率は $\mathrm{Ta}$ 置換にともなって増大するが，

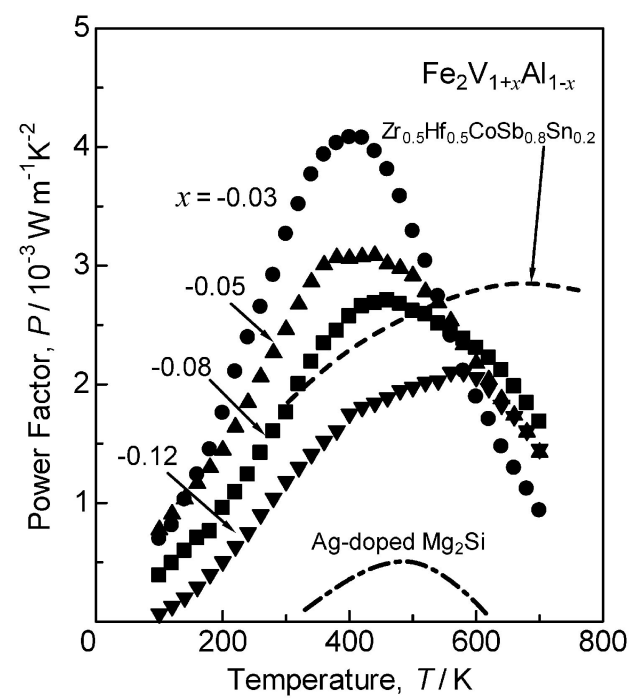

Fig. 5 Temperature dependence of power factor $P$ in $\mathrm{Fe}_{2} \mathrm{~V}_{1+x} \mathrm{Al}_{1-x}$ with $-0.12 \leq x \leq-0.03$. Also plotted in the figure are the values of $P$ for $\mathrm{Zr}_{0.5} \mathrm{Hf}_{0.5} \mathrm{CoSb}_{0.8} \mathrm{Sn}_{0.2}{ }^{30)}$ and $\mathrm{Ag}$-doped $\mathrm{Mg}_{2} \mathrm{Si}^{31}$ 


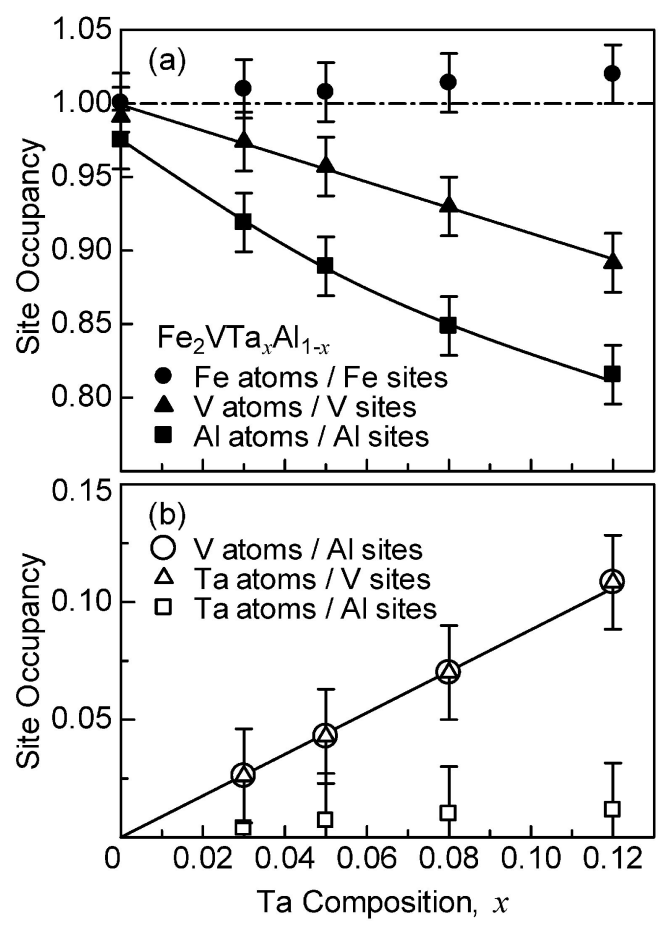

Fig. 6 (a) (b) Site occupancy as a function of Ta composition $x$ for $\mathrm{Fe}_{2} \mathrm{VTa}_{x} \mathrm{Al}_{1-x}$.

$\mathrm{Ta}$ 原子の $\mathrm{Al}$ サイト占有率はほとんど 0 になっている．以 上のことから， $\mathrm{Fe}_{2} \mathrm{VAl}_{1-x} \mathrm{Ta}_{x}$ に打いて，Ta原子は $\mathrm{Al}$ サイ 卜を置換するのではなく，実際には V サイトを占有してお り，そのために押し出された $\mathrm{V}$ 原子が $\mathrm{Al}$ サイトを占有す る。つまり, サイト選択性を考慮した組成式は $\mathrm{Fe}_{2}\left(\mathrm{~V}_{1-x} \mathrm{Ta}_{x}\right)\left(\mathrm{Al}_{1-x} \mathrm{~V}_{x}\right)$ と表され, その結果, $\mathrm{Fe}_{2} \mathrm{~V}_{1+x} \mathrm{Al}_{1-x}$ と同様に $\mathrm{V} / \mathrm{Al}$ 非化学量論効果により出力因子が向上し, $\mathrm{Fe}_{2} \mathrm{~V}_{1-x} \mathrm{~W}_{x} \mathrm{Al}$ と同様に重元素置換により熱伝導率が低減す ると考えられる。これらの相乗効果により， $\mathrm{Fe}_{2} \mathrm{VTa}_{x} \mathrm{Al}_{1-x}$ は優れた熱電特性を示すことが期待できる.

$\mathrm{Fe}_{2} \mathrm{VTa}_{x} \mathrm{Al}_{1-x}$ に扔いて, Ta 置換した場合の VEC は 6 以 上であるのでゼーベック係数の符号は負となり, Fig. 3 とほ ぼ同様な温度依存性を示す。この場合， $x=0.03$ の合金で ゼーベック係数は $-164 \mu \mathrm{V} / \mathrm{K}$ を示した ${ }^{9)}$.さらに, Fig. 3 に示した $\mathrm{V} / \mathrm{Al}$ 非化学量論組成の場合と同様に, ゼーベック 係数のピーク温度が Ta 組成の増加とともに高温側にシフト して抢り， $x=0.12$ に扔いて $560 \mathrm{~K}$ にまで達する9).ピーク 形状は $\mathrm{Ta}$ 組成の増加にともなって緩やかになるため, 広範 囲の温度域で比較的高いゼーベック係数が保たれているが,

Fig. 3 の V/Al 非化学量論組成と比較すると高温側のゼーべ ック係数の絶対值は若干減少する傾向にある.さらに，Ta 置換にともなう電気抵抗率の減少も, $\mathrm{V} / \mathrm{Al}$ 非化学量論組成 の合金とほぼ同様である。また, $\mathrm{Fe}_{2} \mathrm{VTa}_{x} \mathrm{Al}_{1-x}$ は $\mathrm{n}$ 型であ るが, $\mathrm{Fe}_{2}\left(\mathrm{~V}_{1-x} \mathrm{Ta}_{x}\right)\left(\mathrm{Al}_{1-x} \mathrm{~V}_{x}\right)$ のように $\mathrm{Ta}$ の $\mathrm{V}$ サイト選択 性を考慮して $\mathrm{V} / \mathrm{Al}$ 非化学量論組成とすることで， $\mathrm{V}$ リッチ

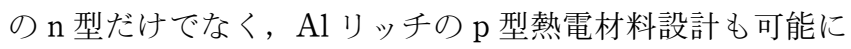
なる.

Fig. 7(a)は, $\mathrm{Fe}_{2} \mathrm{VTa}_{x} \mathrm{Al}_{1-x}$ について $300 \mathrm{~K}$ に抢ける熱厷 導率 $\kappa$ を Ta 組成 $x$ に対してプロットした結果である ${ }^{9}$.

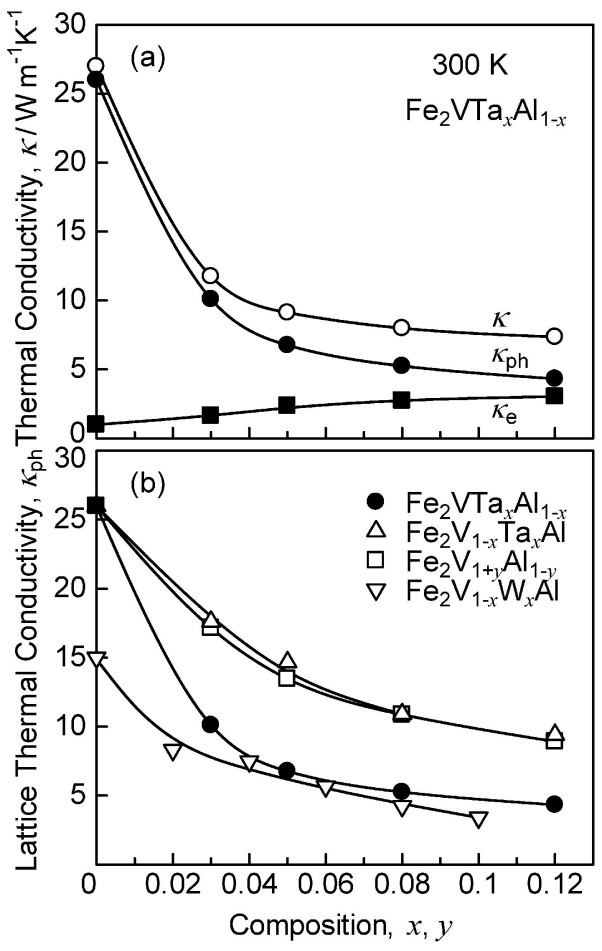

Fig. 7 (a) Thermal conductivity $\kappa$ for $\mathrm{Fe}_{2} \mathrm{VTa}_{x} \mathrm{Al}_{1-x}$ as a function of Ta composition $x . \kappa$ is given by the sum of the electronic $\kappa_{\mathrm{e}}$ and lattice contribution $\kappa_{\mathrm{ph}}$. (b) Lattice thermal conductivity $\kappa_{\text {ph }}$ for $\mathrm{Fe}_{2} \mathrm{VTa}_{x} \mathrm{Al}_{1-x}, \mathrm{Fe}_{2} \mathrm{~V}_{1-x} \mathrm{Ta}_{x} \mathrm{Al}, \mathrm{Fe}_{2} \mathrm{~V}_{1+y} \mathrm{Al}_{1-y}{ }^{8)}$ and $\mathrm{Fe}_{2} \mathrm{~V}_{1-x} \mathrm{~W}_{x} \mathrm{Al}{ }^{32}$ as a function of composition $x, y$.

$\mathrm{Fe}_{2} \operatorname{VAl}(x=0)$ の熱伝導率は $27 \mathrm{~W} / \mathrm{mK}$ であるが，Ta 置換に より約 $7 \mathrm{~W} / \mathrm{mK}$ にまで低下している。一般に，熱伝導率 $\kappa$ はフォノンによる成分 $\kappa_{\mathrm{ph}}$ とキャリアによる成分 $\kappa_{\mathrm{e}}$ の和で 表される．このうちキャリア成分 $\kappa_{\mathrm{e}}$ は, ヴィーデマン・フ ランツ則 $\left(\kappa_{\mathrm{e}}=L_{0} T / \rho, L_{0}\right.$ : ローレンツ数)を仮定すると電気 抵抗率 $\rho$ から求めることができる. Fig. 7 (a) に扔いて測定 した熱伝導率 $\kappa$ と比較すると, 電子成分 $\kappa_{\mathrm{e}}$ は小さく, フォ ハンによる熱伝導 $\kappa_{\mathrm{ph}}$ が支配的であることがわかる。このこ とから，Taで部分置換することによりフォノン散乱の影響 がより強まり, 熱伝導率の低減に極めて有効である。 $\mathrm{Fe}_{2} \mathrm{VTa}_{x} \mathrm{Al}_{1-x}$ における重元素置換の効果を明らかにするた めに, Fig. 7(b)には $\mathrm{Fe}_{2} \mathrm{~V}_{1-x} \mathrm{Ta}_{x} \mathrm{Al}, \mathrm{Fe}_{2} \mathrm{~V}_{1+y} \mathrm{Al}_{1-y}$ 8) および $\mathrm{Fe}_{2} \mathrm{~V}_{1-x} \mathrm{~W}_{x} \mathrm{Al}{ }^{32)}$ 合金の格子熱伝導率 $\kappa_{\mathrm{ph}}$ の組成変化を示 す。まず， $\mathrm{Fe}_{2} \mathrm{~V}_{1-x} \mathrm{Ta}_{x} \mathrm{Al}$ と $\mathrm{Fe}_{2} \mathrm{~V}_{1+y} \mathrm{Al}_{1-y}$ の $\kappa_{\mathrm{ph}}$ はほぼ同程 度の大きさになっている，つまり，重元素置換の効果だけで なく非化学量論組成の効果も熱伝導率低減には同じ程度に有 効であるといえる. $\mathrm{Fe}_{2} \mathrm{VTa}_{x} \mathrm{Al}_{1-x}$ は両方の効果を有してお り，このため $\mathrm{Ta} / \mathrm{V} や \mathrm{~V} / \mathrm{Al}$ 置換のみの合金よりも熱伝導率 の低減効果も大きく表れている。一方， $\mathrm{Fe}_{2} \mathrm{~V}_{1-x} \mathrm{~W}_{x} \mathrm{Al}$ 合金 は焼結体の微細粒効果によりもともと熱伝導率は低いが32), $x=0.04$ 以上の組成では $\mathrm{Fe}_{2} \mathrm{VTa}_{x} \mathrm{Al}_{1-x}$ とほとんど変わらな い結果となっている。したがって, $\mathrm{Fe}_{2} \mathrm{VTa}_{x} \mathrm{Al}_{1-x}$ について も微細粒の焼結体とすることにより, さらに熱伝導率は低減 することが期待できる.

最後に, Fig. 8 は $\mathrm{Fe}_{2} \mathrm{VTa}_{x} \mathrm{Al}_{1-x}$ の無次元性能指数 $Z T$ の 温度依存性である ${ }^{9)} .400 \sim 500 \mathrm{~K}$ の温度域で $Z T=0.21$ 0.22 という高い值を示して抢り, これは出力因子の増大と 


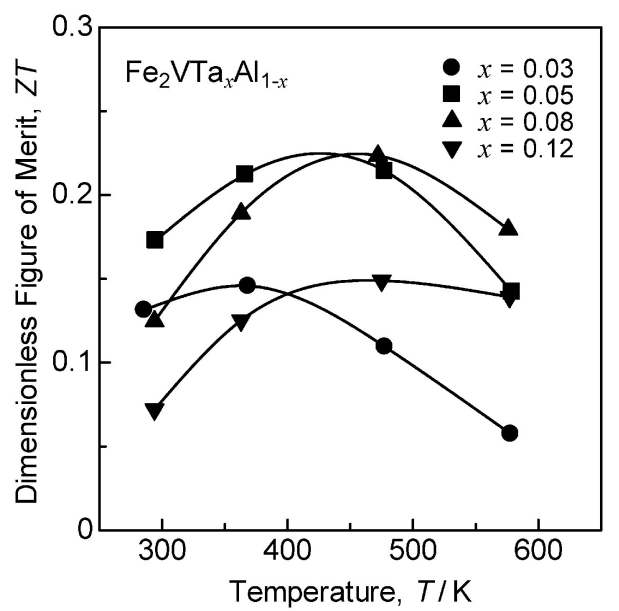

Fig. 8 Dimensionless figure of merit $Z T$ for $\mathrm{Fe}_{2} \mathrm{VTa}_{x} \mathrm{Al}_{1-x}$ with $0.03 \leq x \leq 0.12$ as a function of temperature.

熱伝導率の低減の相乗効果によるものである. $\mathrm{Fe}_{2} \mathrm{~V}_{1-x} \mathrm{~W}_{x} \mathrm{Al}$ 焼結体の $Z T$ は $400 \mathrm{~K}$ では 0.2 であり, $500 \mathrm{~K}$ では急激に減 少することが報告されている32).これに対して， $\mathrm{Fe}_{2} \mathrm{VTa}_{0.05} \mathrm{Al}_{0.95}$ では広い温度範囲で $Z T=0.21 \sim 0.22$ を示 しており， $\mathrm{Fe}_{2} \mathrm{VAl}$ 系のなかでは高性能な熱電材料である.

\section{4. おわりに}

化学量論組成 $\mathrm{Fe}_{2} \mathrm{VAl}$ において, ホイスラー構造における 置換元素のサイト選択性を利用して元素置換すると，置換元 素によってゼーベック係数の正負の符号も変化するので, 熱 電材料として $\mathrm{p}-\mathrm{n}$ 特性を制御することができる.さらに, 各種元素で置換した $\mathrm{Fe}_{2} \mathrm{VAl}$ 系熱電材料のゼーベック係数を 置換元素の組成ではなく，価電子濃度 $(V E C)$ でプロットす ると, ベースの $\mathrm{Fe}_{2} \mathrm{VAl}$ に対する $V E C=6$ を中心として, ゼーベック係数の符号は正から負に急激に变化しており, 置 換元素の種類によらずにすべてのデータがユニバーサルな 1 本の曲線にのることが確認されている，つまり，擬ギャップ 系では元素置換によって電子構造を大きく変化させることな く，フェルミ準位のみを剛体バンド的にシフトさせることが 可能である. しかし一方で, 熱電材料としてはユニバーサル 曲線上の最高值を超えるような性能向上は難しいことを意味 している，ところが最近の研究によって， $\mathrm{Fe} / \mathrm{V}$ 非化学量論 組成の合金に元素置換すると，化学量論組成の合金を上回る ようなゼーベック係数の増大が可能であることが明らかとな った．さらに， $\mathrm{V} / \mathrm{Al}$ 非化学量論組成の合金では，元素置換 をしなくてもゼーベック係数が大幅に増大するだけでなく， ピーク温度も室温付近から 500 $600 \mathrm{~K}$ まで上昇するように なる.このため, 組成制御のみで熱電性能のピーク温度をチ ューニングすることができるので，熱源温度に対応した材料 設計が可能となる。この合金では V の代わりに Ta で置換 することにより， $\mathrm{V} / \mathrm{Al}$ 非化学量論組成の合金と同じように ゼーベック係数が増大して電気抵抗率が減少するだけでな く, さらに熱伝導率も大幅に低減できるため，400～ $500 \mathrm{~K}$ で $Z T=0.21 \sim 0.22$ が得られている.
$\mathrm{Fe}_{2} \mathrm{VAl}$ 系はもともと熱伝導率が高いために, 従来の熱電 材料と比べて変換効率では劣るものの, 出力因子を評価指標 とした発電性能は $600 \mathrm{~K}$ 以下の温度域に拈いて ZrNiSn ハー フホイスラー化合物や $\mathrm{Mg}_{2} \mathrm{Si}$ 化合物よりも高くなってい る。これは同じ温度差を与えた場合には， $\mathrm{Fe}_{2} \mathrm{VAl}$ 系がより 大きな電力を発生できることを意味しており，移動体のよう に持続的に廃熱が発生する環境で利用するうえでは， ZTの 高い材料でなくても，むしろ出力因子が高い材料の方が有利 である。また，発電性能が高いことは高出力密度化に寄与す るので, 熱電発電システムの小型化が可能である. とくに $\mathrm{Fe}_{2} \mathrm{VAl}$ 系は材料密度も低いために質量あたりの出力が大き く,さらに耐熱性や耐久性も兼ね備えた材料であるので, 移 動体用の熱電発電モジュールとして早期の実用化が期待され る.

本研究は, 科学研究費補助金 (基盤研究 (B)：課題番号 23360279 抢よび基盤研究 (C) : 課題番号 26420664)により 行われた成果をまとめたものである.

文献

1) Y. Nishino and K. Tsuchiya: Materia Japan 44(2005) 629.

2) Y. Nishino, M. Kato, S. Asano, K. Soda, M. Hayasaki and U. Mizutani: Phys. Rev. Lett. 79(1997) 1909-1912.

3) G. Y. Guo, G. A. Botton and Y. Nishino: J. Phys. Condens. Matter 10(1998) L119-L126.

4) D. J. Singh and I. I. Mazin: Phys. Rev. B 57 (1998) 1435214356.

5) Y. Nishino: Materia Japan 44(2005) 648-653.

6) Y. Nishino: The Science of Complex Alloy Phases, ed. by T. B. Massalski and P. E. A. Turch, (TMS, Warrendale, 2005) pp. 325-344.

7) Y. Nishino and M. Mikami: Kinzoku 79(2009) 231-236.

8) H. Miyazaki, S. Tanaka, N. Ide, K. Soda and Y. Nishino: Mater Res. Express 1(2014) 015901-1-9.

9) K. Renard, A. Mori, Y. Yamada, S. Tanaka, H. Miyazaki and Y. Nishino: J. Appl. Phys. 115(2014) 033707-1-7.

10) G. D. Mahan and J. O. Sofo: Proc. Natl. Acad. Sci. USA 93 (1996) 7436-7439.

11) N. F. Mott and H. Jones: The Theory of the Properties of Metals, (Clarendon Press, 1936).

12) Y. Nishino, H. Kato, M. Kato and U. Mizutani: Phys. Rev. B 63 (2001) 233303-1-4.

13) Y. Hanada, R. O. Suzuki and K. Ono: J. Alloy. Compd. 329 (2001) 63-68.

14) C. S. Lue and Y.-K. Kuo: Phys. Rev. B 66(2002) 085121-1-5.

15) H. Kato, M. Kato, Y. Nishino, U. Mizutani and S. Asano: J. Japan Inst. Metals 65 (2001) 652-656.

16) H. Matsuura, Y. Nishino, U. Mizutani and S. Asano: J. Japan Inst. Metals 66 (2002) 767-771

17) Y. Nishino, S. Deguchi and U. Mizutani: Phys. Rev. B 74(2006 $115115-1-6$

18) C. S. Lue, C. F. Chen, J. Y. Lin, Y. T. Yu and Y. K. Kuo: Phys Rev. B 75(2007) 064204-1-6.

19) M. Vasundhara, V. Srinivas and V. V. Rao: Phys. Rev. B 77 (2008) 224415-1-8.

20) C. S. Lue, R. F. Liu, M. Y. Song, K. K. Wu and Y. K. Kuo: Phys. Rev. B 78(2008) 165117-1-5.

21) E. J. Skoug, C. Zhou, Y. Pei and D. T. Morelli: J. Electron. Mater. 38(2009) 1221-1223.

22) S. Fujii, Y. Ienaga, S. Ishida and S. Asano: J. Phys. Soc. Japan 72(2003) 698-704.

23) Y. Nishino and Y. Tamada: J. Appl. Phys. 115(2014) 123707-18.

24) U. Mizutani: Hume-Rothery Rules for Structurally Complex Alloy Phases, (CRC Press, New York, 2011) pp. 249-283.

25) K. Soda, S. Harada, M. Kato, S. Yagi, M. Inukai, H. Miyazaki, Y. Sandaiji, Y. Tamada, S. Tanaka, T. Sugiura and Y. Nishino: 
J. Electron Spectrosc. Relat. Phenom. 184(2011) 236.

26) H. Scherrer and S. Scherrer: CRC Handbook of Thermoelectrics, ed. by D. M. Rowe, (CRC Press, New York, 1995) pp. 211-237.

27) H. Miyazaki, K. Renard, M. Inukai, K. Soda and Y. Nishino: J. Electron Spectrosc. Relat. Phenom. 195 (2014) 185-188.

28) H. Muta, T. Kanemitsu, K. Kurosaki and S. Yamanaka: J. Alloy. Compd. 469(2009) 50-55.

29) K. Kambe and H. Udono: J. Electron. Mater. 43(2014) 22122217.
30) X. Yan, G. Joshi, W. Liu, Y. Lan, H. Wang, S. Lee, J. W. Simonson, S. J. Poon, T. M. Tritt, G. Chen and Z. F. Ren: Nano Lett. 11(2011) 556-560.

31) T. Sakamoto, T. Iida, A. Matsumoto, Y. Honda, T. Nemoto, J. Sato, T. Nakajima, H. Taguchi and Y. Takanashi: J. Electron. Mater. 39(2010) 1708-1713.

32) M. Mikami, Y. Kinemuchi, K. Ozaki, Y. Terazawa and T. Takeuchi: J. Appl. Phys. 111 (2012) 093710-1-6. 